\title{
PEMBAGIAN WARIS PADA MASYARAKAT BIMA DI TINJAU DARI ASPEK SOSIOLOGI HUKUM
}

\author{
Jainuddin, M. Hum. \\ Institut Agama Islam (IAI) Muhammadiyah Bima \\ Jln. Anggrek No. 16 Ranggo Na'e Kota Bima \\ jainuddin.ptais015@gmail.com
}

\section{Abstrak}

Pembagian waris pada masyarakat Bima sangat mengedepankan asas hukum Islam yang dianggap sebagai yang utama untuk menyelesaikan persoalan waris tersebut. Namun disisi lain juga justru persoalan warisan menjadi salah satu aspek yang menimbulkan perselisihan yang berimbas pada renggangnya silaturahmi antara sesama saudara kandung, paman, bibi, dan bukan saaudara kandung. Bahkan yang lebih parah lagi adalah mengklaim warisan milik anak yatim dan piatu hanya karena hubungan sedarah dengan orang tua anak tersebut. Perilaku tersebut disebabkan karena menganggap anak yang ditinggalkan tersebut tidak memiliki pendidikan atau pemahaman tentang masalah tersebut. Tulisan ini mencoba mengurai pola pembagian waris pada masyarakat Bima di tinjau dari aspek sosiologi hukum. Tulisan ini akan menggunakan pendekatan sosiologi Hukum dengan teori Hukum sebagai perilku sosial. Digunakan untuk melihat implementasi perubahan perilaku kehidupan masyarakat Bima dalam hal pembagian harta waris. Persoalan warisan menjadi salah satu aspek yang menimbulkan perselisihan yang berimbas pada renggangnya silaturahmi antara sesama saudara kandung, paman, bibi, dan bukan saaudara kandung. 
Bahkan yang lebih parah lagi adalah mengklaim warisan milik anak yatim dan piatu hanya karena hubungan sedarah dengan orang tua anak tersebut. Dalam pembagian warisan, ada kecenderungan yang dilakukan oleh masyarakat, bahwa tanah warisan yang dibawah oleh bapak akan diwariskan kepada anak laki-laki jika punya anak laki-laki; sedangkan tanah warisan yang dibawah oleh ibu cenderung menjadi bagian warisan anak perempuan, kecuali tidak ada anak perempuan turun ke anak laki-laki dan sebaliknya. Namun ada juga pembagian warisan dilakukan berdasarkan atas dasar kesepakatan bersama tanpa membedakan haarta bawaan masing-masing (suami atau istri).

\section{Kata Kunci : Waris, Masyarakat Bima, Sosiologi Hukum.}

\section{A. Pendahuluan}

Masyarakat Bima merupakan salah satu suku yang hidup di ujung timur propinsi Nusa tenggara Barat. Masyarakat Bima biasa disebut sebagai Suku "Mbojo" yang memiliki ciri khas warna kulit Sawo matang. Mayoritas masyarakat bima bemata pencaharian sebagai petani, peternak, perkebunan, dan nelayan. Masyarakat Bima sebagian besar hidup di dataran tinggi pegunungan, dan sebagian kecil hidup di daerah pesisir pantai laut. Karakter masyarakat Bima sangat beragam diantaranya pantang menyerah dan taat terhadap agama yang dianutnya. Hal tersebut sangat dipengaruhi oleh kondisi iklim alam tempat masyarakat bertempat tinggal.

Sebagai masyarakat yang mayoritas taat kepada ajaran agama yang dianutnya tentu fanatisme terhadap ajaran agama yang dianutnya sangat melekat dalam berbagai aspek kehidupan. Masyarakat Bima "Dou Mbojo" sangat memuliakan para ulama "Tuan Guru". Masyarakat Bima dalam mengamalkan ajaran Islam sangat beragam diantaranya 
pertama sebagian masyarakat Bima menganut ajaran agama Islam yang sufisme dan di anggap sebagai ajaran Islam yang benar. Hal tersebut dapat di lihat dari pemahaman mereka tentang kedudukan tabib yang dalam Bahasa Bima biasa disebut sebagai "Sando" untuk mengobati berbagai macam penyakit dalam diri manusia itu sendiri. Bagi masyarakat Bima "Sando" merupakan orang yang ahli dalam menyembuhkan segala macam dan jenis penyakit yang diderita oleh manusia.

Kedua, penganut ajaran Islam puritan, golongan ini senantiasa disebut dengan "dou parsi" "orang persi". Golongan ini tidak memiliki kesamaan pemahaman keagamaan dengan golongan pertama. Hal tersebut bias di lihat bagaimana perilaku beragama merekaa sangat berbeda. "dou parsi" mengamaaalkan ajaran agamanya harus senantiasa sesuai dengan ajaraan yang tertuang dalam Al-Qur'an dan Al-Hadits.

Hukum adat Mbojo Bima merupakan salah satu hukum adat yang terus hidup, tumbuh dan berkembang dari zaman ke zaman seiring dengan perkembangan ilmu pengetahuan dan teknologi. Hukum Adat Mbojo Bima ini berlaku sejak zaman kerajaan, zaman penjajahan, dan zaman kemerdekaan hingga sekarang ini. Hukum Adat Mbojo Bima hingga saat sekarang masih tetap ditaati dan dijunjung tinggi oleh masyarakat adat mbojo-Bima dimanapun berada. Sistem hukum yang dianut dalam Sistem kekerabatan adat Mbojo-Bima sistem parental, di mana anak laki-laki dan perempuan mempunyai hak yang sama untuk memperoleh hak warisan berupa tanah dan rumah dari orang tuanya sesuai dengan bagian yang ditentukan menurut hukum yang berlaku.

Dalam hal pembagian waris, masyarakat Bima sangat mengedepankan asas hukum Islam yang dianggap sebagai yang utama untuk menyelesaikan persoalan waris tersebut. Namun disisi lain juga justru persoalan warisan menjadi salah satu aspek yang menimbulkan perselisihan yang berimbas 
pada renggangnya silaturahmi antara sesama saudara kandung, paman, bibi, dan bukan saaudara kandung. Bahkan yang lebih parah lagi adalah mengklaim warisan milik anak yatim dan piatu hanya karena hubungan sedarah dengan orang tua anak tersebut. Perilaku tersebut disebabkan karena menganggap anak yang ditinggalkan tersebut tidak memiliki pendidikan atau pemahaman tentang masalah tersebut.

Polemik tersebut merupakan gambaran pergeseran nilai kehidupan sebagian masyarakat Bima yang sudah melekat dan tertanam sejak dari dulu. Warisan karakter kehidupan masyarakat Bima sudah cenderung berorientasi pada kehidupan dunia sehingga melupakan akhirat. Sekitar tahun 1980-an, masyarakat Bima ketika melakukan transaksi jual beli tanah hanya dengan sesuatu barang-barang tertentu yang dianggap sangat berharga, dan bahkan hanya dengan proses akad secara lisan pun bisa terlaksana atas dasar asas kekeluargaan yang sudah melekat. Setelah prubahan arus zaman dan kemajuan teknologi dan informasi hal tersebut bisa ditarik kembali dengan alasan bahwa orang tuanya tidak pernah menjual dengan dasar tidak memiliki akte jual beli. Begitupun dengan persoalan warisan, sebagian masyarakat Bima cenderung menggunakan dali-dalil hukum untuk membatalkan ikrar lisan yang didasari dengan keihlasan orang tua kepada anak-anak yang sudah ditinggalkan.

Oleh sebab itu, pembahasan dalam tulisan ini mencoba mengurai sistim pebagian waris pada masyarakat Bima di tinjau dari aspek sosiologi hukum. Tulisan ini akan menggunakan teori perilaku social untuk melihat implementasi tentang perubahan perilaku kehidupan masyarakat Bima.

Hukum waris sangat erat kaitannya dengan ruang lingkup kehidupan manusia, sebab setiap manusia pasti akan mengalami peristiwa hukum kematian. Akibat hukum yang selanjutnya timbul dengan terjadinya peristiwa hukum 
kematian seseorang, diantaranya adalah masalah bagaimana penguasaan dan kelanjutan hak-hak dan kewajiban-kewajiban seseorang yang meninggal dunia itu.

Hukum Islam sebagai salah satu pranata sosial memiliki dua fungsi, fungsi pertama sebagai kontrol sosial, yaitu hukum Islam diletakkan sebagai hukum Tuhan, yang selain sebagai kontrol sosial sekaligus sebagai social engineering terhadap keberadaan suatu komunitas masyarakat. Sedang kontrol yang kedua adalah sebagai nilai dalam proses perubahan sosial yaitu hukum lebih merupakan produk sejarah yang dalam batasbatas tertentu diletakkan sebagai justifikasi terhadap tuntutan perubahan sosial, budaya, dan politik. $^{1}$

\section{B. Hukum Sebagai Perilaku}

Sebagaimana diketahui bahwa sosiologi Hukum merupakan salah satu cabang ilmu yang menyoroti hukum sebagai perilaku diantaranya perilaku etis (perilaku yang didasari dari hati nurani). Perilaku etis mencakup perilaku di bidang kepercayaan, kesusilaan, kesopanan dan hukum. Perilaku teratur merupakan kebiasaan yang konstan (Sosiologis) serta tertuju pada keinginan untuk mencapai kedamaian, yakni suatu keserasian antara ketertiban dengan ketentraman (Psikologis). Perilaku unik merupakan keputusankeputusan yang diambil oleh fungsionaris hukum/masyarakat (sosiologis) dan tujuannya adalah untuk mencapai kedamaian (Psikologis).

Untuk dapat melihat perilaku manusia sebagai hukum diperlukan kesediaan mengubah konsep mengenai hukum yang tidak hanya sebagai peraturan (rule) tetapi juga sebagai perilaku (behavior). Hukum sebagai teks hanya akan menjadi

${ }^{1}$ Ahmad Rofiq, Pembaharuan Hukum Islam di Indonesia, Gama Media, Yogyakarta, 2001, Hlm. 98. 
hidup melalui perantaraan manusia, dalam kepustakaan sosiologi hukum, perantaraan tersebut disebut sebagai mobilisasi hukum (Black.1980). perilaku atau tindakan menusia dapat menambah dan mengubah teks hukum itu sendiri.

Menurut Rahardjo dalam bukunya yang berjudul hukum dan perilaku mengatakan bahwa hukum mendapatkan koreksi yang sangat besar sebagai teks dan mengeliminasi faktor serta peran manusia terhadap hukum itu sendiri kurang mendapatkan posisi sentral dalam hukum berkat dari sosiologi hukum dan antropoligi hukum yang mereformasi hukum itu sendiri bahwa peran manusia tidak lepas dari hukum itu sendiri. Sejak sosiologi hukum mmamsuk maka hukum sebagai teks atau dokumen-dokumen tertulis mendapat koreksi besar dari dua ilmu tersebut.

\section{Hukum Waris}

Dalam literatur hukum Indonesia sering digunakan kata "waris" atau warisan. Kata tersebut berasal dari bahasa Arab akan tetapi dalam praktek lebih lazim disebut "Pusaka". Bentuk kata kerjanya Warastra Yaritsu dan kata masdarnya Mirats. Masdar yang lain menurut ilmu saraf masih ada tiga yaitu wirsan, wirasatan dan irsan. Sedangkan kata waris adalah orang yang mendapat warisan atau pusaka. ${ }^{2}$

Dalam literatur hukum arab ditemukan penggunaaan kata Mawarits, bentuk kata jamak dari Mirats. Namun banyak dalam kitab fikih tidak menggunakan kata mawarits sedang kata yang digunakan adalah faraid lebih dahulu dari pada kata mawaris. Rasullulah Saw menggunakan kata faraid dan tidak menggunnakan kata mawarits. Hadis riwayat Ibnu Abas Ma'ud berbunyi: dari Ibnu Abas dia berkata, Rasullulah

2 Maryati Bachtiar, Hukum Waris Islam di Pandang dari Perspektif berkeadilan gender, Journal Ilmu hukum Volume 3 No. 1

Sangaji Jurnal Pemikiran Syariah dan Hukum 
bersabda: Pelajarilah Al-Qur'an dan ajarkanlah pada orang lain. Pelajari pula faraid dan ajarkan kepada orang-orang (HR Ahmad). ${ }^{3}$

Dalam KUH Perdata (BW) menurut Pasal 830 "Pewarisan hanya terjadi karena apabila ada kematian". Apabila belum ada kematian maka belum terjadi warisan. Wiryono Prodjodikoro mengatakan: "warisan adalah soal apakah dan bagaimanakah pelbagai hak-hak dan kewajiban-kewajiban tentang kekayaan seseorang pada waktu ia meninggal dunia akan beralih kepada orang lain yang masih hidup."

sistem hukum kewarisan menurut KUH Perdata, sistem kewarisan menurut hukum adat dan sistem kewarisan menurut hukum Islam. ${ }^{4}$ Sebagai negara yang mayoritas penduduknya beragama Islam dimungkinkan banyak dari anggota masyarakat yang mengunakan sistem hukum Islam. Tetapi seiring dengan perkembangangan zaman yang ditandai dengan kemajuan teknologi prinsip-prinsip dalam hukum Islam terus mengalami kemajuan yang pesat dan selalu mengikuti perubahan zaman untuk kemaslahatan umat tanpa membedakan laki-laki maupun perempuan.

Berikut penjelasan tentang tiga hukum waris yang sudah diakui di Indonesia antara lain:

\section{Hukum Waris Adat.}

Hukum waris dalam hukum adat selalu dimaknai serangkaian peraturan yang mengatur peralihan harta peninggalan atau harta warisan dari satu generasi ke generasi lain, baik mengenai benda material maupun immaterial. Sekaligus menunjukkan bahwa proses kewarisan tidak harus berlangsung dalam suasana kematian. Hal itu berarti bahwa hukum waris adat

${ }^{3}$ H Achmad Kuzari, Sistem Asabah Dasar Pemindahan Hak Milik atas Harta Tinggalan, Dar al-jal, Beirut, 1973, Hlm. 168

4 Eman Suparman, Hukum Waris Indonesia, Rajawali Press, Bandung, 2005, Hlm. 12 
mencakup pula masalah tindakan-tindakan mengenai pelimpahan harta benda semasa seseorang masih hidup. ${ }^{5}$

Kenyataan bahwa kontekstualisasi hukum waris dalam masyarakat, kematian bukan merupakan salah satu syarat melaksanakan peralihan harta warisan. Temuan itu sebagai pembeda dalam pelaksanaan hukum waris adat dengan hukum waris Islam. Peralihan harta dalam hukum waris Islam, ketika pewaris masih hidup disebut hibah, namun lambat laun hibah itu pada akhirnya menjelma menjadi harta warisan pada saat pewaris meninggal dunia.

Hibah adalah suatu tindakan hukum dalam hukum waris adat, bila seseorang menghadiahkan sebagian atau bagian tertentu dari harta waris kepada seseorang tertentu. Dengan catatan bagian itu tidak melebihi sepertiga dari seluruh harta bendanya. Orang tertentu dalam hukum waris adat adalah orang yang bukan termasuk ahli waris anggota keluarga. ${ }^{6}$

\section{Hukum Waris Islam.}

Asas hukum dalam pewarisan Islam tidak memandang perbedaan antara laki-laki dengan perempuan, semua ahli waris baik laki-laki maupun perempuan mempunyai hak yang sama sebagai ahli waris. Tetapi hanyalah perbandingannya saja yang berbeda. Memang di dalam hukum waris Islam yang ditekankan adalah keadilan yang berimbang, bukanlah keadilan yang sama rata sebagai sesama ahli waris. Karena prinsip inilah yang sering menjadi polemik dan perdebatan yang kadang kala menimbulkan persengketaan diantara para ahli waris.

5 Bushar Muhammad, Pokok-Pokok Hukum Adat (Cet. VIII; Jakarta: Pradnya Paramita, 2002), hlm. 39.

${ }^{6} \mathrm{Ibid}$, hlm. 40

Sangaji Jurnal Pemikiran Syariah dan Hukum 
Berikut penjelasan singkat asas Hukum waris Islam antara lain:

a) Asas Ijbari

Secara etimologi "Ijbari" mengandung arti paksaan, yaitu melakukan sesuatu di luar kehendak sendiri. Dalam hal hukum waris berarti terjadinya peralihan harta seseorang yang telah meninggal kepada yang masih hidup terjadi dengan sendirinya. Artinya tanpa adanya perbuatan hukum atau pernyataan kehendak dari pewaris. Dengan perkataan lain adanya kematian pewaris secara otomatis hartanya beralih kepada ahli warisnya.

Asas Ijbari ini dapat dilihat dari berbagai segi yaitu: 1. Dari peralihan harta; 2. dari segi jumlah harta yang beralih; 3 dari segi kepada siapa harta itu akan beralih. Ketentuan asas Ijbari ini dapat dilihat antara lain dalam ketentuan Al-Qur'an, surat An-Nisa ayat 7 yang menyelaskan bahwa: bagi seorang laki-laki maupun perempuan ada nasib dari harta peninggalan orang tuanya atau dari karib kerabatnya, kata nasib dalam ayat tersebut dalam arti saham, bagian atau jatah dari harta peninggalan si pewaris.

b) Asas Bilateral

Yang dimaksud dengan asas bilateral dalam hukum kewarisan Islam adalah seseorang menerima hak kewarisan bersumber dari kedua belah pihak kerabat, yaitu dari garis keturunan perempuan maupun keturunan laki-laki. Asas bilateral ini secara tegas dapat ditemui dalam ketentuan Al-Qur'an surat An-Nisa ayat 7, 11, 12 dan 176, antara lain dalam ayat 7 dikemukakan bahwa seorang laki-laki berhak memperoleh warisan dari pihak ayahnya maupun ibunya. Begitu juga dengan perempuan mendapat 
warisan dari kedua belah pihak orang tuanya. Asas bilateral ini juga berlaku pula untuk kerabat garis ke samping (yaitu melalui ayah dan ibu).

c) Asas Individual

Pengertian asas individual ini adalah: setiap ahli waris (secara individu) berhak atas bagian yang didapatkan tanpa terikat kepada ahli waris lainya. Dengan demikian bagian yang diperoleh oleh ahli waris secara individu berhak mendapatkan semua harta yang telah menjadi bagiannya. Ketentuan ini dapat dijumpai dalam ketentuan Al-Qur'an surat AnNisa ayat 7 yang mengemukakan bahwa bagian masingmasing ahli waris ditentukan secara individu.

d) Asas Keadilan Berimbang

Asas keadilan berimbang maksudnya adalah keseimbangan antara hak dengan kewajiban dan keseimbangan antara yang diperoleh dengan kebutuhan dan kegunaan. Dengan perkataan lain dapat dikemukakan bahwa faktor jenis kelamin tidak menentukan dalam hak kewarisan. Dasar hukum asas ini adalah dalam ketentuan Al-Qur'an surat An-Nisa ayat 7, 11, 12 dan 179.

e) Kewarisan Akibat kematian

Hukum waris Islam memandang bahwa terjadinya peralihan harta hanya semata-mata karena adanya kematian. Dengan perkataan lain harta seseorang tidak dapat beralih apabila belum ada kematian. Apabila pewaris masih hidup maka peralihan harta tidak dapat dilakukan dengan pewarisan.

Masalah harta warisan biasanya menjadi sumber perselisihan dalam keluarga, terutama terkait dengan ketentuan mengenai siapa yang berhak dan siapa yang tidak berhak serta ketentuan mengenai bagian masing- 
masing agar tidak memicu perselisihan yang akhirnya dapat berujung pada keretakan ikatan kekeluargaan. ${ }^{7}$ Merujuk pada realitas demikian hukum waris Islam menata secara sistematis agar siapa pun yang terkait dalam konteks hak hendaknya berlaku seadil-adilnya dengan memberikan ketentuan bagian masing-masing.

Kaitannya dengan rukun kewarisan dapat ditemukan dalam tiga hal sebagai berikut;

1) Al-muwarris (pewaris), yaitu orang yang mewariskan dan yang meninggal dunia. Baik meninggal dunia secara hakiki atau sebab putusan hakim, seseorang dinyatakan mati berdasarkan sebab.

2) Al-maurus (harta warisan), harta peninggalan si mati yang akan diwariskan setelah dikurangi biaya perawatan jenazah, utang, zakat, dan setelah digunakan untuk melaksanakan wasiat. Harta warisan disebut juga miras, irs, turas, dan tirkah. Harta atau hak yang dialihkan kepada ahli waris dari orang yang mewariskan.

3) Al-waris (ahli waris) yaitu orang yang akan diwarisi yang mempunyai hubungan dengan al-muwarris baik hubungan itu sebab kekeluargaan (nasab) maupun perkawinan. ${ }^{8}$

Ketiga rukun tersebut merupakan sesuatu yang sangat mutlak dan saling berkaitan satu sama lain. Akan tetapi ketentuan tersebut sering kali terabaikan dalam kehidupan masyarakat.

Hak-hak yang berhubungan dengan harta peninggalan itu ada empat. Keempatnya tidak sama

7 Darmawan, Hukum Kewarisan Islam di Indonesia (Cet.I; Surabaya: UIN Sunan Ampel Press, 2014), hlm. 7

${ }^{8} \mathrm{Ibid}, \mathrm{hlm} 30$ 
kedudukannya, sebagiannya ada yang lebih kuat dari yang lain sehingga ia didahulukan atas yang lain untuk dikeluarkan dari peninggalan. ${ }^{9}$ Harta benda yang diwarisi itu, sebelum dibagi hendaknya mempertimbangkan dan dilakukan hal-hal sebagai berikut:

1) Biaya perawatan jenazah yaitu biaya yang digunakan untuk merawat jenazah mulai dari memandikan, mengkafani, menguburkan dan lain-lain yang menyangkut penyelesaian jenazah sampai selesai dimakamkan. Mazhab Hanabilah berpendapat bahwa biaya-biaya untuk menyelenggerakan pengurusan jenazah sebaiknya didahulukan daripada membayar utang, sekalipun utang itu bersangkut paut dengan suatu benda. Akan tetapi, jumhur yakni Malikiyah, Syafi'iyah, dan Hanafiyyah berpendapat hendaknya mendahulukan utang yang bersangkut paut dengan benda.

2) Pembayaran hutang si mayit, yaitu wajib dilunasi dengan diambilkan dari harta peninggalannya dengan cara sesudah harta peninggalan tadi dikurangi untuk keperluan tajhiz.

3) Wasiat yaitu merupakan hak yang diberikan oleh agama kepada seseorang atas harta bendanya tanpa persetujuan ahli waris, dan tidak boleh lebih dari sepertiga harta bendanya, diberikan kepada seseorang. ${ }^{10}$

Melihat sebab-sebab untuk memperoleh warisan dalam hukum waris Islam ada tiga sebab antara lain:

1) Nasab Hakiki (kerabat yang sebenarnya), ahli waris dengan sebab hubungan darah atau kerabat sering

9 Sayyid Sabiq, Figh Sunnah terj. Hlm 4

${ }^{10}$ Darmawan, Hukum Kewarisan di Indonesia, hlm. 110-114

Sangaji Jurnal Pemikiran Syariah dan Hukum 
disebut ahli waris nasabiyah, artinya orang berhak memperoleh bagian harta peninggalan karena ada hubungan darah (nasab). ${ }^{11}$

2) Nasab Hukmi (wala-kerabat karena memerdekakan), sabda Rasulullah Saw: "Wala itu adalah kerabat seperti kekerabatan karena nasab" (HR. Ibnu Hibban dan AlHakim dan dia mensahihkan pula)."

3) Perkawinan yang shahih, seseorang dapat memperoleh harta warisan disebabkan adanya perkawinan antara si mayit dengan seseorang. ${ }^{12}$

Selain dengan beberapa ketentuan dalam hukum waris Islam, maka ada tiga syarat pewarisan, sebagai berikut:

1) Kematian orang yang mewariskan, baik kematian secara nyata ataupun kematian secara hukum, misalnya seorang hakim memutuskan kematian seseorang yang hilang. Keputusan tersebut menjadikan orang yang hilang sebagai orang yang mati secara hakiki, atau mati menurut dugaan seperti seseorang memukul seorang perempuan yang hamil sehingga janinnya gugur dalam keadaan mati, maka janin yang gugur itu dianggap hidup sekalipun hidupnya itu belum nyata.

2) Ahli waris masih hidup setelah orang yang mewariskan meninggal, meskipun hidupnya itu secara hukum, misalnya janin dalam kandungan. Janin dalam kandungan secara hukum dianggap hidup, karena mungkin rohnya belum ditiupkan. Apabila tidak diketahui bahwa ahli waris itu hidup sesudah orang yang mewariskan meninggal, seperti karena tenggelam atau terbakar atau tertimbun; maka

${ }^{11}$ QS. al-Anfal : 75

${ }^{12}$ QS. Al-Nisa: 12 
di antara mereka itu tidak ada waris mewarisi jika mereka itu termasuk orang-orang yang saling mewarisi. Dan harta masing-masing mereka itu dibagikan kepada ahli waris yang masih hidup.

3) Bila tidak ada penghalang yang menghalangi pewarisan. ${ }^{13}$

Orang yang terhalang untuk mendapatkan warisan adalah orang yang sebenarnya memenuhi sebab-sebab untuk memperoleh warisan, tetapi dia kehilangan hak untuk memperolehnya. Orang yang demikian dinamakan mahrum. Penghalang itu ada empat:

1) Perbudakan: baik orang itu menjadi budak dengan sempurna atau tidak.

2) Pembunuhan dengan sengaja yang diharamkan. Apabila pewaris membunuh orang yang mewariskan dengan cara zalim, maka dia tidak lagi mewarisi, karena Nabi Saw bersabda; “Orang yang membunuh tidak mendapatkan warisan sedikit pun." Adapun pembunuhan yang tidak disengaja, maka para ulama berbeda pendapat di dalamnya. Berkata al-Syafi'i: Setiap pembunuhan menghalangi pewarisan, sekalipun pembunuhan itu dilakukan oleh anak kecil atau orang gila, dan sekalipun dengan cara yang benar seperti had atau qishash. Mazhab Maliki berkata: Sesungguhnya pembunuhan yang menghalangi pewarisan itu adalah pembunuhan yang sengaja bermusuhan, baik langsung ataupun mengalami perantaraan. Undang-undang Warisan Mesir mengambil pendapat ini dalam pasal lima belas, yang bunyinya; "Di antara penyebab yang

${ }^{13}$ Sayid Sabiq, Fikih Sunah, Terjemah: Mahyuddin Syaf, hlm. 6

Sangaji Jurnal Pemikiran Syariah dan Hukum 
menghalangi pewarisan ialah membunuh orang yang mewariskan dengan sengaja, baik pembunuh itu pelaku utama, serikat, ataupun saksi palsu yang kesaksiannya mengakibatkan hukum bunuh dan pelaksanaannya bagi orang yang mewariskan, jika pembunuhan itu pembunuhan yang tidak benar

3) atau tidak beralasan; sedang pembunuh itu orang yang berakal dan sudah berumur lima belas tahun; kecuali kalau dia melakukan hak membela diri yang sah.

4) Berlainan Agama. Dengan demikian seorang muslim tidak mewarisi dari orang kafir, dan seorang kafir tidak mewarisi dari seorang muslim; karena hadits yang diriwayatkan oleh empat orang ahli hadits, dari Usamah bin Zaid bahwa Nabi Saw bersabda: "Seorang muslim tidak mewarisi dari seorang kafir, seorang kafirpun tidak mewarisi dari seorang muslim." Diriwayatkan oleh Muaz, Mu'awiyah, Ibnu Musayyab, Masruq dan al-Nakha'i, bahwa sesungguhnya seorang muslim itu mewarisi dari seorang kafir; dan tidak sebalinya. Yang demikian itu seperti halnya seorang muslim laki-laki boleh menikah dengan seorang kafir perempuan dan seorang kafir laki-laki

5) tidak boleh menikah dengan seorang muslim perempuan.Adapun orang-orang yang bukan muslim, maka sebagian mereka mewarisi sebagian yang lain, karena mereka dianggap satu agama.

6) Berbeda negara (tidak menghalangi). Yang dimaksud berbeda negara adalah berbeda kebangsaannya. Perbedaan kebangsaan ini tidak menghalangi pewarisan di antara kalangan kaum muslimin, karena seorang muslim itu mewarisi dari seorang 
muslim, sekalipun jauh negaranya dan berbeda wilayahnya. ${ }^{14}$

Orang-orang yang berhak menerima warisan, menurut mazhab Hanafi, tersusun sebagai berikut :

1) 'Ashabul furudh

2) 'Ashabul nasabiyah

3) 'Ashabul sababiyah

4) Radd kepada 'ashabul furudh

5) Zhawul arham.

6) maulal muwalah

7) Orang yang diakui nasabnya kepada orang lain

8) Orang yang menerima wasiat melebihi sepertiga harta peninggalan

9) Baitul mal. ${ }^{15}$

Beberapa orang yang disebutkan itu yakni orangorang baik ada hubungan darah (nasab) maupun dengan sebab perkawinan dan dengan sebab-sebab hukum. Akan tetapi, jika pewaris tidak meninggalkan ahli waris, maka harta peninggalannya itu dapat disimpan di Baitul Mal untuk dimanfaat bagi kepentingan umum.

\section{Pola Pembagian Waris Pada Masyarakat Bima}

Sejak kerajaan Bima menganut agama Islam, maka aturan hukum yang dijadikan pedoman dalam pelaksanaan pemerintahan dan pelaksanaan kegiatan kehidupan masyarakat sehari-hari berdasarkan hukum agama Islam dan hukum adat.

Hukum agama Islam berdasarkan Al-Qur'an dan alHadist, sedangkan hukum adat berdasarkan nilai-nilai yang baik, dan nilainilai moral yang seharusnya dilakukan sesuai

${ }^{14}$ Ibid, hlm. 7

${ }^{15}$ Ibid hlm 7

Sangaji Jurnal Pemikiran Syariah dan Hukum 
dengan kesepakatan masyarakat, muncul dan berkembang di kalangan masyarakat adat. Hukum Islam dilaksanakan dan ditegakkan oleh para alim ulama dan kiyai-kiyai, dan selalu ditaati dan dihormati oleh masyarakat. Sedangkan hukum adat adalah hukum yang hidup, tumbuh dan berkembang di dalam masyarakat dan dilaksanakan serta ditegakkan oleh para pemuka adat atau tetua adat, atau penguasa adat serta oleh pemerintah kerajaan yang dipimpin oleh Raja. Dengan demikian pemerintahan kerajaan Mbojo-Bima dibawah pimpinan Raja Bima, yangdalam pelaksanaan pemerintahan dan pelayanan kepentingan kemasyarakatan dilakukan secara bersamasama dan berdampingan dengan tokoh-tokoh agama dan tokoh-tokok adat Mbojo di seluruh wilayah kerajaan MbojoBima. Hukum Islam yang dianut oleh masyarakat Islam di wilayah Kerajaan Mbojo-Bima yang berdasarkan Al-Qur'an dan Hadist meliputi hukum kenegaraan, hukum keperdataan, hukum pidana/jinayah. Dengan demikian penyelenggaraan pemerintahan kerajaan dan penyelenggaraan kehidupan masyarakat Islam sehari berdasarkan hukum Islam, misalnya: syarat sebagai pemimpin masyarakat adat di kalangan masyarakat adat Mbojo-Bima yang beragama Islam harus beragama Islam. Pelaksanaan perkawinan, pembagian harta warisan, jual beli, tukar menukar dilakukan berdasarkan hukum Islam juga.

Di bidang keperdataan, khususnya di bidang kewarisanmasyarakat hukum adat Mbojo-Bima menganut sistem parental, oleh karena itu pembagian warisan dalam masyarakat hukum adat Mbojo-Bima berdasarkan penjelasan dari para responden dan informan dilakukan dengan ketentuan sebagai berikut:

1. Hak waris terbuka bagi ahli waris bisa semasih hidup dan bisa setelah pewaris meninggal dunia (bahasa Bima: "Cengga Mori ro Cengga Made"); 
2. Pembagian warisan semasa hidup pewaris dilakukan berdasarkan musyawarah dan kesepakatan antara pewaris dengan para ahli waris (bahasa Bima:Cengga Mori=pembagian semasa hidup) dengan cara "Mafakaweki dou matua labo Anaana" (musyawarah mufakat antara pewaris dengan anak-anak/para ahli waris) dihadiri oleh "Dou Matua-tua" (orang tua-tua atau yang dituakan) yang dihormati dan disegani dalam keluarga, sekaligus sebagai saksi.

3. Pembagian warisan yang dilakukan setelah pewaris meninggal dunia dilakukan berdasarkan musyawarah dan kesepakatan para ahli waris, baik dilakukan berdasarkan hukum Agama Islam maupun Hukum Adat (bahasa Bima: Cengga Made cara na" Mafakaweki, Londo ro Mai" (musyawarah mufakat para ahli waris) dihadirioleh "Dou Matua-tua" (orang tua-tua atau yang dituakan) yang dihormati dan disegani dalam keluarga, sekaligus sebagai saksi;

4. Porsi masing-masing ahli waris ditentukan berdasarkan kesepakatan dalam musyawarah, bisa berdasarkan hukum Agama Islam 2:1. (bahasa bima:"Salemba: Sancuu'); Salemba artinya sepikul, yaitu 2(dua) bagian untuk anak laki-laki, dan Sancuu' artinya sejinjing, yaitu 1(satu) bagian untuk anak perempuan, dan bisa juga berdasarkan hukum Adat, yaitu kebiasaan yang turun temurun 1:1 (bahasa Bima: "sancuu":"sancuu"); Sancuu, artinya sejinjing, yaitu 1(satu) bagian untuk anak laki-laki dan 1(satu) bagian pula untuk anak perempuan (atas dasar musyawarah). ${ }^{16}$

${ }_{16}$ M. Arba, Any Suryani \& Shinta Andriyani, Perspektif Hukum Agraria Nasional dan Hukum Adat, Jatiswara Vol.34. No. 2 tahun 2019. hlm. 180

Sangaji Jurnal Pemikiran Syariah dan Hukum 


\section{E. Kesimpulan}

Dari uraian tersebut dapat disimpulkan bahwa pola pembagian waris pada masyarakat Bima berdasarkan Hukum Islam dan atas dasar kesepakatan semua ahli waris. Namun disisi lain juga justru persoalan warisan menjadi salah satu aspek yang menimbulkan perselisihan yang berimbas pada renggangnya silaturahmi antara sesama saudara kandung, paman, bibi, dan bukan saaudara kandung. Bahkan yang lebih parah lagi adalah mengklaim warisan milik anak yatim dan piatu hanya karena hubungan sedarah dengan orang tua anak tersebut.

Berdasarkan ketentuan-ketentuan tersebut, maka pelaksanaan pembagian warisan berupa tanah yang dilakukan oleh masyarakat Bima dilakukan baik semasa hidup maupun setelah pewaris meninggal dunia, dengan porsi bagian masingmasing ahli waris ditentukan berdasarkan ketentuan hukum agama 2:1 atau berdasarkan hukum adat 1:1 (kesepakatan) semua ahli waris. Di dalam masyarakat Bima mengenal jenis harta yang dimiliki yang berupa tanah, yaitu: harta "Tanah Pusaka" (Dana Pasaka), yaitu tanah yang diperoleh melalui pewarisan yang turun temurun; dan "Tanah Pencaharian" (Dana Pancaharia") yaitu tanah yang diperoleh oleh pewaris dari hasil usaha selama perkawinan. Dalam pembagian warisan, ada kecenderungan yang dilakukan oleh masyarakat, bahwa tanah warisan yang dibawah oleh bapak akan diwariskan kepada anak laki-laki jika punya anak laki-laki; sedangkan tanah warisan yang dibawah oleh ibu cenderung menjadi bagian warisan anak perempuan, kecuali tidak ada anak perempuan turun ke anak laki-laki dan sebaliknya. Namun ada juga pembagian warisan dilakukan berdasarkan atas dasar kesepakatan bersama tanpa membedakan haarta bawaan masing-masing (suami atau istri). 


\section{Daftar Pustaka}

Esmi Warassih, Pranata Hukum: Sebuah Telaah Sosiologis, diedit oleh

Karolus Kopong Medan dan Mahmotarom HR. (Semarang: PT. Suryandaru Utama, 2005, halaman).

Mochtar Kusumaatmadja, Hukum, Masyarakat dan Pembinaan Hukum Nasional, Bandung, Bina Cipta 1976.

Soerjono Soekanto, Pengantar Sosiologi Hukum, 1997 Pustaka Bahasa, Departemen Pendidikan

Nasional, Kamus Besar Bahasa Indonesia, Edisi ketiga, Balai Pustaka, Jakarta, 2003.

M. Arba, Any Suryani \& Shinta Andriyani, Perspektif Hukum Agraria Nasional dan Hukum Adat, Jatiswara Vol.34. No. 2 tahun 2019.

Darmawan, Hukum Kewarisan Islam di Indonesia (Cet.I; Surabaya:

UIN Sunan Ampel Press, 2014),

H Achmad Kuzari, Sistem Asabah Dasar Pemindahan Hak Milik atas Harta Tinggalan, Dar al-jal, Beirut, 1973.

Eman Suparman, Hukum Waris Indonesia, Rajawali Press, Bandung, 2005.

Bushar Muhammad, Pokok-Pokok Hukum Adat (Cet. VIII; Jakarta: Pradnya Paramita, 2002).

Ahmad Rofiq, Pembaharuan Hukum Islam di Indonesia, Gama Media, Yogyakarta, 2001.

Maryati Bachtiar, Hukum Waris Islam di Pandang dari Perspektif berkeadilan gender, Journal Ilmu hukum Volume 3 No. 1

Sangaji Jurnal Pemikiran Syariah dan Hukum 